\title{
Sly Mouths and Silver Tongues: the Dynamics of Psychological Persuasion in Ancient China
}

Bouches sournoises, langues spécieuses : dynamique de la persuasion en Chine ancienne

口蜜腹劍, 油嘴滑舌——中國古代游説之動力

\section{Albert Galvany}

\section{OpenEdition}

\section{Journals}

\section{Electronic version}

URL: http://journals.openedition.org/extremeorient/250

DOI: 10.4000/extremeorient.250

ISSN: 2108-7105

\section{Publisher}

Presses universitaires de Vincennes

\section{Printed version}

Date of publication: 1 November 2012

Number of pages: $15-40$

ISBN: 978-2-84292-352-5

ISSN: 0754-5010

\section{Electronic reference}

Albert Galvany, "Sly Mouths and Silver Tongues: the Dynamics of Psychological Persuasion in Ancient China », Extrême-Orient Extrême-Occident [Online], 34 | 2012, Online since 01 November 2015, connection on 20 April 2019. URL : http://journals.openedition.org/extremeorient/250; DOI : 10.4000/ extremeorient. 250 


\title{
Sly Mouths and Silver Tongues: the Dynamics of Psychological Persuasion in Ancient China
}

\author{
Albert Galvany ${ }^{1}$
}

\section{The enemy is already inside the gates: from $\mathrm{Zi} \mathrm{Lu}$ to $\mathrm{Zi}$ Gong}

The project for political and moral restoration conceived by Confucius seems to have been largely shaped by a clear awareness of the dangers associated with discourse, or with unseemly, careless use of language. Mistrust of verbal communication, denunciation of rhetorical manoeuvres and censure of any language that was not subordinate to morals are all recurrent elements in Confucius' thought. The fundamental role of the Master within the community of his disciples was to guarantee strict correspondence between the property of language and the property of action. Hence Confucius evokes a commitment between words and facts that, if it ever existed in antiquity - the idealised image of which he draws upon to project his own ambitions - had broken down by his own times: "In olden times, one was loathe to speak for fear of being unable to put one's maxims into practice." 2 It is not surprising, then, that the nobleman or gentleman (junzi) - the figure that paradigmatically embodies the moral standard compatible with the Confucian programme - is ashamed of any word that exceeds his deeds, that is, of any discourse that is not immediately and

1. This research has been supported by a Marie Curie Intra-European Fellowship (PIEFGA-2010-274566) within the 7th European Community Framework Programme for Research and Technological Development. I would like to thank both Jean Levi and Paul van Els for their comments on early drafts of this essay. I am also indebted to the reviewers of Extrême-Orient, Extrême-Occident for providing incisive suggestions and valuable corrections. Of course, all remaining mistakes and infelicities are my own responsibility.

2. ципуи IV.21. 
incontrovertibly translated into its corresponding action. ${ }^{3}$ In contrast with this concept of language, which was defined by the will to specify and conserve in a rigorous fashion the relationship between words and things, between names and facts, between the plane of enunciation and the plane of action, the sociopolitical context in which the Confucian doctrine emerged was already pervaded with a growing and almost overpowering interest in the persuasive effects of language. Such tenacious attempts to prevail over the flow of words point to a reality dominated precisely by an amoral and even wilfully immoral resort to discourse. In this situation, Confucius' project is articulated and organised around the notion of moral quality (ren) which, with regard to one's relationship with words, goes back to a constellation of ethical concepts that validate an appropriate use of language, for example the concept of sincerity or credibility (xin). ${ }^{4}$ However, in the early centuries of the Zhou dynasty the term ren tended to mean splendour of form, of physical beauty as befits individuals belonging to the noble classes. This, in turn, found an equivalent in the realm of discourse with the phonetically and graphically related concept of ning, meaning appealing in word, or eloquent. ${ }^{5}$ Throughout the Analects (Lunyu) one can confirm the extent to which Confucius strove to break the connection between these two originally linked notions and even to make them opposite and incompatible. It is essential, in his view, to shun eloquent people since this attribute of adroit acuity in wielding words, far from epitomising nobility, signals danger, and it therefore has nothing to do with the moral aspiration to which the notion ren now harks back. ${ }^{6}$ The antagonism between the two notions in the Analects is brought about by way of accomplishing a slippage between levels. This appears in the explicit association established between moral quality as expressed by the term ren, and restraint, temporisation or circumspection in use of language $(n a) .^{7}$ As a result of this total inversion, the term thus shifts from initially referring

3. Lипуи XIV.27; see also Lипуи V.25. For an analysis of Confucius' use and conception of language, see Jean Levi 2002: 90-130 and the developments by Jean-François Billeter 2005: 180-188.

4. See Lипуи I.3, I.7, XIII.20, XV.6.

5. It is highly likely that Confucius was the first person in history to use the term ren as an ethical concept. It rarely appears in written sources pre-dating his times and, indeed, when it does appear, it bears no relation to the moral load it would subsequently be given. See Lin Yü-sheng 1974-1975: 172-204. As David Nivison observes, in archaic Chinese the term ning was pronounced *nieng and was a graphic modification of its cognate ren which, in fact, was pronounced *nien. See Nivison 1999: 745-812, especially 751. One passage in the Analects suggests that this link between the two notions was also evident for some of Confucius' contemporaries: Lunyu V.5.

6. See Lипуи I.3, XV.11 and XVI.4.

7. Lunyu IV.24 and XIII.27. 
to agility in discourse (ning) to being conflated with frugality and prudence of speech. Confucius endorses this new identification between moral quality and rhetorical abstemiousness precisely by means of ingenious wordplay. Questioned by his disciple Sima Niu about moral quality, the Master, almost certainly trying to counteract his penchant for eloquence, pronounces, "Moral quality (ren) consists in being sparing $\left(\right.$ ren $\left.^{\mathrm{a}}\right)$ with words." ${ }^{8}$ As evident in this anecdote about Sima Niu, the tension between these two antagonistic ways of understanding and experiencing language is not only articulated around the axis defined by the Confucian community and the outside world but it is also lodged in the very heart of the school. The heterogeneous group of disciples attending the Master also reflects the predominance and the extent of the inappropriate or even deviant use of words. There are several episodes included in the Analects in which Confucius is obliged to criticise and keep his disciples in check when they flaunt an unworthy relationship with words. To give one of the more evident examples:

$\mathrm{Zi} \mathrm{Lu} \mathrm{had} \mathrm{Zi} \mathrm{Gao} \mathrm{appointed} \mathrm{governor} \mathrm{of} \mathrm{Bi.} \mathrm{The} \mathrm{Master} \mathrm{said,} \mathrm{"You} \mathrm{are} \mathrm{injuring} \mathrm{the} \mathrm{son}$ of another man." Zi Lu replied, "He will be in charge of the people and the altars of the Land and the Grain. Why must only men who read books be deemed cultivated?" The Master exclaimed, "This is why I detest glib-tongued people (ning)!"9

$\mathrm{Zi} \mathrm{Gao,} \mathrm{the} \mathrm{disciple} \mathrm{whom} \mathrm{Zi} \mathrm{Lu}$ wishes to establish in the government of $\mathrm{Bi}$, is naturally not the most gifted pupil and neither is he the most competent for fulfilling a task of such magnitude. Confucius describes him at another point in the Analects, along with some of his fellow disciples, including $\mathrm{Zi} \mathrm{Lu} \mathrm{himself,} \mathrm{as}$ being something of a cloddish dolt. ${ }^{10}$ Confucius' first reproach to $\mathrm{Zi} \mathrm{Lu}$ should be interpreted then as a warning on the disproportion between the responsibility demanded by the position and the scant aptitudes of $\mathrm{Zi} \mathrm{Lu's} \mathrm{candidate.} \mathrm{The}$ latter, far from recognising his error, obstinately defends his decision and, in so doing, attacks the Master. First, he attempts to convince him that, whatever Confucius might believe, the destiny he has in mind for $\mathrm{Zi} \mathrm{Gao} \mathrm{is} \mathrm{appropriate}$ for him and, second, he simultaneously tries to elude and neutralise the Master's admonishment by wielding against him words from his own teachings. Indeed, the sentence "Why must only men who read books be deemed cultivated?" goes directly back to one of the maxims to be found in the selfsame text:

Zixia said: "As for persons who care for character more than beauty, who in serving their parents exert themselves utterly, who would sacrifice their life in the service of their ruler, and who, in interactions with colleagues and friends, make good on their

\footnotetext{
8. Lипуи XII.3.

9. Lипуи XI.25.

10. Lипуи XI.18.
} 
word; however much people say of such persons that they are unschooled, I would insist that they are well educated indeed." 11

The impertinent disciple attempts to turn the Master's own teaching against him. Impervious to the nuances and the deep meaning of the words with which he has been challenged, $\mathrm{Zi}$ Lu responds exclusively to the logic of debate and addresses the Master as if he were a mere adversary to be routed in a sterile dialectical skirmish. Hence Confucius responds with all his contempt for people who stoop to eloquence (ning). The characteristic that $\mathrm{Zi} \mathrm{Lu}$ shares at this point with smooth-tongued orators undermines from within the very foundations of the Master's thinking. It reveals that, driven by the power of words, even one of the privileged beneficiaries of the doctrine that supposedly aims to put an end to the abuse of language by means of establishing a moral and ritual code has come to betray the basic principles of this teaching. This anecdote expresses in all its radicalness the tension hovering over the question of language, showing the deep unease and suspicions with which the precursor of philosophical reflection in China goes about his project. Nevertheless, despite the reserve and even rejection repeatedly expressed by Confucius, some of the disciples closest to him stand out precisely for their oratorical skills.

Notable among them is Zi Gong, who embodied the new kind of man who was to mark the Warring States period. He held prestigious official positions in $\mathrm{Lu}$ and Wei, was a prudent politician, a canny diplomat and a redoubtable negotiator who, moreover, had entrepreneurial talents and a flair for financial operations. ${ }^{12}$ Above all, $\mathrm{Zi}$ Gong excelled in rhetorical skills. A passage from the Analects depicts him, together with Zai Wo, as someone distinguished for his ability in speech (yan yu) ${ }^{13}$; the Mengzi affirms that, Zi Gong "was excellent at composing persuasive speeches" (shan wei shuo $\mathrm{ci}$ ) ${ }^{14}$; and Sima Qian also considers that he was "an able orator gifted with a sharp tongue" (li kou qiao $c i) .{ }^{15}$ It is not surprising, then, that when Confucius is questioned in the Analects as to his views on the morally superior man (junzi), the Master, modulating his response to the particularities, leanings and deficiencies of his interlocutor, should take the opportunity to remind him that this ethical paradigm begins by

11. Lипуи I.7. See also Lипуи I.8 and I.14.

12. Sima Qian 司馬遷 1959: chap. LXVII, 2201.

13. Lипуи XI.3.

14. Wang Yunwu 王雲五 1984: 58.

15. Sima Qian 1959: chap. LXVII, 2195. The Lunheng includes Zi Gong among the orators with sweet words and clever speech (言甘辭巧): Huang Hui 黃暉 1990: chap. LXXX, 1115. For a more detailed study on the influence of $\mathrm{Zi}$ Gong in the diplomatic and rhetorical traditions of antiquity, see the study by Zhuan Jianping 傳劍平 1995: 83-101. 
putting one's words into practice and abiding by them (xian xing qi yan, er hou cong zhi,${ }^{16}$ a clear allusion to $\mathrm{Zi}$ Gong's inclination to a rhetorical, or nothing less than an amoral, use of language.

However, while Confucius vehemently censures such qualities, when pushed by some adverse situation, he is obliged to have recourse to them himself. Hence, according to some ancient sources, fearing that the state of Qi was about to launch a military attack on the state of Lu, endangering the tombs of his ancestors, he agrees that Zi Gong, whose talents as an orator and political adviser he was very well aware of, should set off on a diplomatic mission in an attempt to counter the plans of Qi ${ }^{17}$ In order to achieve his objective, Zi Gong manages to obtain an audience with several monarchs and, thanks to his power of persuasion, is able to impose his strategy. By means of a cunning diplomatic plot involving the states of Qi, Wu, Yue and Jin, the crafty Zi Gong is able to head off the military assault on Lu that was initially scheduled by Qi, getting Qi to abandon the plan and, instead, turn its armies against the state of $\mathrm{Wu} .{ }^{18}$ The consequences of this complex and delicate diplomatic mission by Zi Gong are summarized in another early text as follows: "In one fell swoop Zi Gong brought civil war to Qi, destroyed Wu, advanced Jin, and strengthened Yue." 19 If we are to give credence to these written sources, the disciple successfully completed the mission thanks to his rhetorical skills but this also entails recognising the inevitable, definitive defeat of the Confucian programme. While Confucius'proposal requests a transparent world in which internal and external,

16. ᄂипуи II.13.

17. There can be no doubt that Confucius, at least in what one may glean from the Analects, recognises Zi Gong's practical (political, diplomatic, economic) qualities since when the latter asks him for his opinion of his own person (Lunyu V.4), the Master employs the term qi 器 ("vessel” or, in the wider sense, "utensil” or "instrument") to portray him. However, the moral ambiguity harboured in the term-since in Lunyu II.12, Confucius declares that the noble man, exemplar of the morally adequate individual, is not a vessel-most probably expresses the ambivalence awakened by $\mathrm{Zi}$ Gong and his attributes in the bosom of the Confucian community. In the account of this diplomatic mission to stop the attack by Qi, the Shiji states: "Zi Lu asked for permission to leave, but Confucius stopped him. Zi Zhang and Zishi asked for permission to set off, but Confucius would not agree to this. Zi Gong asked for permission to set off, and Confucius agreed to this." (Shiji: chap. LXVII, 2197) It seems clear then that, according to Sima Qian, the Master decided to select $\mathrm{Zi}$ Gong because of his talent as negotiator and diplomat.

18. Sima Qian 1959: 2197-2201. See also Chen Shike 陳士珂 1980: chap. XXXVII, 213; and Xiang Zonglu 向宗魯 1989: chap. XII, 296.

19. Li Bujia 李步嘉 1992: chap. I, 1. The intricate diplomatic triumph achieved by Zi Gong for the state of Lu is described fully in detail in another section of this text: chap. IX, 162-167. For a translation and study of this chapter, see Olivia Milburn 2010: 205-219. 
intention and expression, the announced and the executed, necessarily coincide, the realms in which his realistic disciple moves are governed by opacity, secrecy, and pretence. The success of Zi Gong's mission means that the survival of Lu, emblem of traditional moral values, necessarily requires the adoption of qualities (the arts of persuasion, wily intelligence, inveiglement, slyness, and so on) which can only signify its decadence and categorical ruin. If the traditions of $\mathrm{Lu}$ represent the past, it is necessary to recognise that the present and the future seem to belong to these itinerant orators who, thanks to their persuasive eloquence, are capable of effectively conducting political manoeuvres governed less by probity and loyalty than by acumen and, in the end, by subterfuge and seduction. As Confucius himself puts it, with both clarity and bitterness:

Without the eloquence of the priest Tuo or the beauty of prince Chao of Song, it is difficult to succeed in today's world. ${ }^{20}$

In the new context of the Warring States period, mastery of the word, the art of seducing listeners become necessary instruments not only for acceding to the heart of political power through obtaining promotion, or to an adviser's position by imposing one's own terms on adversaries and competitors, but also because the very future of the state now depends on the aptitudes of the itinerant orators. ${ }^{21}$ In a time of intrigues, discourse becomes one of the pillars of the political mechanism on which the stability or instability of the different powers depends. In order to carry out the convoluted plans hatched over a long time by far-sighted minds with the aim of directing diplomatic manoeuvres, plotting conspiracies, forging alliances or foiling military operations, it is essential to know how to persuade a person by passing off false as true and true as false. The emergence of this new breed of statesman, the salaried counsellor, brings a completely different hue to the delicate balance of political and diplomatic forces: at once adviser, spy and double agent, the itinerant orator becomes the

20. Lunyu VI.14. The priest Tuo was renowned for his speech-making eloquence and skills (Yang Bojun 楊伯君 1996, Ding gong 定公 Year 4: 1535), while Prince Chao of Song was famous for his captivating beauty (Cheng Shude 程樹德 1980: 397-399).

21. Of course, not all orators and advisers were necessarily itinerant in the Warring States period. Nevertheless, it seems clear that the appearance of this new class of wandering officials, which was part of an extraordinary general process of social mobility, brought about far-reaching changes in institutions and practices as well as in the mentality of the times. The fact that, at least potentially, even permanently appointed officers could move to another kingdom or, on the contrary, could accept in their courts advisers hailing from other parts had an enormous impact. For further discussion of this, see Cho-yun Hsu 1965; and Jean Levi 2007: 805-823. 
true protagonist of the almost infinite succession of risky, complicated and astute machinations through which the state's destiny is now being decided. ${ }^{22}$

In the course of presenting his case, the itinerant orator who sets out to win the support of the sovereign or acceptance among influential courtiers resorts to all kinds of rhetorical procedures. Naturally, his spiel includes the linking up of logically arranged arguments that will bear the fruit of conviction thanks to the power of their formal architecture. It must also dispel any doubts his audience might harbour as to the matter in hand. Furthermore, a frequent resort to expressions of humility and other ornamental touches, precision in selection of quotes and proverbial expressions, shrewd use of analogies, and deftness in organising, deploying and propounding premises and propositions all determine the success or failure of an oral intervention. Nevertheless, and despite the fact that this in no way suggests any relegation of the complex conglomerate of the purely formal elements of rhetorical endeavour to a mere theory of manipulation, the influence of such exploitation of the psychological factors intervening in any project of persuasion - detection and opportune utilization of passions, inclinations, vacillations and weaknesses of listeners or interlocutor, and so on - is not to be denied either. ${ }^{23}$ Hence, as I shall attempt to demonstrate below, in most of the classical Chinese writings that present the reader with reflections on the mechanisms of persuasion, or that expound on rhetorical techniques, one finds a manifest awareness of the fact that canny husbanding of these psychological tactics that appeal to the irrational elements of the audience constitutes an essential tool for any orator. It is not only a question of convincing one's interlocutors through well-reasoned arguments but also of captivating them, fascinating them, moving them and, where necessary, intimidating them. Devoid of any moral commitment that would oblige them to respect the correspondence between designations and realities, and willing to exploit the emotions of their listeners to their own advantage so as to attain their own goals, able advisers and diplomats like Zi Gong would certainly be the living embodiment of this diverse and ambivalent facet of rhetoric in ancient China.

22. For a complete description of the ascent to power of the itinerant orators and of discourse as an instrument of political effectiveness, see the contributions of Jean Levi 1989: 6185; and 1992: 49-89.

23. With regard to the influence of psychological factors in conceptions of rhetoric in ancient China-in other words, the elements that, to use the terms of classical western theories of rhetoric, are considered to pertain not so much to reason $(\log o s)$ as to emotions (pathos) - see Garrett 1993: 19-39. 


\section{Persuasion as flattery: the imperative of adaptation}

The prevailing profile of the orator in these times is that of a true mercenary of words, a man who has cast off all scruples and any vestige of moral commitment both to the truth of his assertions and fidelity to his duty. Hence, the figure of the wandering orator and the power of the word that he incarnates give rise to the most devoted admiration in the political and philosophical literature of the Warring States, along with the deepest unease and constant dark boding about the imminent ambush of betrayal. The great intellectuals of the period insistently point out the orators - and, in general, anyone who sees language as a mere instrument of persuasion independently of any sense being conveyed-as constituting the germ of the political and social upheavals of the times, the true root of all the evils and misfortunes threatening the nation:

The ruler of men, frequently relegated to a minor role in the conversations and discussions, and with few opportunities to participate in the debates and diatribes, is easily moved through sophistry and persuasion. Ministers turn to the eloquent advisers of foreign states in the hope that, thanks to the refined effectiveness of their allocutions and their fashionable expressions, the ruler will act in favour of their particular interests. They seduce him with the appeal of benefits and dismay him with fear of calamities so that with their hollow verbiage they quickly make him totally subservient to their will. All these are called "fashionable practices." ${ }^{24}$

Again, the same writers coincide in unanimously signalling the growing importance acquired by silver tongues through this new political and social mechanism of the art of persuasion, to such an extent that even thinkers who, like Xunzi, proclaim themselves adversaries of rhetoric do not hesitate to recognise the enormous power of words:

Words of praise from another are warmer than clothing of linen and silk. The wound caused by words is deeper than that of spears and halberds. Thus that one can find no place to walk through the breadth of the earth is not because the earth is not tranquil but because the danger to every step of the traveller lies generally with words. ${ }^{25}$

24. Chen Qiyou 陳奇猷 2000: chap. IX, 182. See also Chen Qiyou 2000: chap. XLIX, 1114.

25. Wang Xianqian 王先謙 1997: chap. IV, 33. Translation by Knoblock 1988: 186. Another illustration of this may be found in the opening chapter of the legalist text traditionally attributed to Shang Yang 商鞅, the Shang jun shu 商君書 or The Book of Lord Shang. The author (or authors) of this compilation of texts - attributed to the influential statesmanopens the work with a description of the debate between Shang Yang and the rival ministers Gan Long 甘龍 and Du Zhi 杜摰 over reforming the political institutions of the state of Qin, which was then governed by the Duke Xiao 孝公 (r. 361-338 BCE). It is still surprising that one of the paradigmatic figures in the struggle against all forms of oratorical refinement should be somehow obliged to resort to a scene in which triumph 
Extremely dangerous ground which requires the most scrupulous prudence and caution, language also constitutes a powerful weapon through which the success of any enterprise can be guaranteed. In the fundamentally agonistic context of political operations and diplomacy within the court, with the itinerant orators as the key players, very often the art of oratory in ancient China tends to be identified with the art of war and of strategic intelligence. Overcoming the enemy's resistance on the battlefield is comparable with the strivings of rhetoric to convince an interlocutor by routing him. The conception of strategic war and the emergence of the figure of the strategist have their perfect reflection, in the sphere of discourse, in the orator. A fragment from the Lüshi chunqiu offers an illustrative example with regard to this close correlation between the art of war and the art of psychological persuasion:

Those who are adept in the art of speaking resemble those able warriors who, on adapting to the other, make the adversary's strength their own and emulate his movements of advance or retreat. They project neither forms nor figures but live and expand in keeping with the rhythms of others, while their voice is an echo whose tone is now intense and now modulated. However powerful or talented the other may be, they eventually take control of his destiny. ${ }^{26}$

If exhaustive knowledge of the adversary is a basic requisite in the art of war, since, in the last instance, every strategy depends on adequately adapting (yin) to the rival, in the case of the art of persuasion, ability to penetrate the mind of the interlocutor and thus scrutinise his preferences and weaknesses, his convictions and vacillations, is also essential. Unlike what generally happens with the Greek sophists, the Chinese orators do not address an auditorium, which is to say that their speeches are not intended to convince a majority, and neither are they aimed at a more or less numerous group of listeners, but are more or less exclusively for the ears of the person who holds absolute power: the sovereign. ${ }^{27}$ In this singular situation, the task of the adviser who speaks to the person who possesses political authority becomes especially risky and dangerous. The orator

over ideological adversaries by way of greater powers of persuasion is presented as necessary and unavoidable when it comes to consolidating his political project (Jiang Lihong 蔣禮鴻 1986: chap. I, 1-6).

26. Chen Qiyou 陳奇猷 2002: chap. XV.5,913. Su Qin 蘇秦 himself establishes an explicit relationship between the techniques of persuasion and diplomatic dexterity as a form of combat or war: Fan Xiangyong 范祥雍 2008: chap. XII.5, 670-676; Sima Qian 1959: chap. LXIX, 2242-2261. See also Raphals 1992: 117-123.

27. For an interesting comparison between Greek eloquence when seeking to persuade the listeners in an auditorium and the Chinese form as focused on the person of the sovereign, see Lloyd 1996: 74-92. 
is exposed to the arbitrary will of the prince and is therefore obliged to calibrate and minutely ponder all the elements of his performance: the choice of the moment, of tone, of analogies and of examples becomes vital, not only for the success of his plans but even for his very survival. Pitting his word against the absolute authority of the prince, he might be lavished with praise or condemned to death. The success or failure of his intervention depends to a great extent on the knowledge he has of the man he is addressing, or the reading he makes of his psychological profile.

In general terms, the difficulty of persuasion consists in examining the mind of the person one is addressing in order to find the accurate words. If we speak of benefits to someone who is only concerned with renown, he will deem us grasping and we shall be despised and rejected; yet if we speak of virtue to someone who thinks only of benefits, we shall be branded as stupid and we shall have strayed from the crux of the matter without being able to attain any promotion. ${ }^{28}$

All this signifies that the art of persuasion is frequently reduced to a sort of technique of adulation where the supreme aim is to be able to accurately select propositions that will exalt the qualities and tastes of the interlocutor while simultaneously avoiding anything that might irritate him or expose him in any way. Once again the analogy with military thinking weighs in here. In war, as the Sunzi bingfa repeats over and over again, there is nothing permanent. There are no recipes or formulas that will be valid forever and neither are the circumstances of any one battle ever repeated. This is a dynamic process which, as such, requires continuous adaptation to all the circumstances relevant to the combat and, in particular, to the adversary.

Military dispositions are like water: just as the disposition of water is to avoid heights and precipitate downwards, the disposition of the army is to avoid the consistent and to attack where there is absence. And just as water adapts its form to the land, the army adapts its strategy of victory to the enemy. In effect, just as water lacks a permanent form, in war there is no permanent strategic potential either. He who is able to win by adapting to the variations and transformations of the adversary is called "inscrutable." 29

28. Chen Qiyou, 2000: chap. XII, 254. See also Wang Xianqian 1997: chap. V, 85.

29. Yang Bingan 楊丙安 1999: chap. VI, 124-125. In the same sense, the chapter devoted to military strategy in the Huainanzi sustains: "Everything that has a form (xing) can be vanquished. It is always possible to adapt somehow to anything that has a form. This is why the wise man hides his form in nothingness and lets his mind roam in emptiness. A barrier can block the passing of the wind and of water more than of cold and heat for the latter two have no form ( $w$ u xing) and can penetrate the most solid state, passing through metal and stone, reaching the most remote confines all the way to the ninth 
Adaptation to the adversary is as necessary for the orator's strategy as adaptation to the lie of the land is for water. However, if water can deploy this huge potential for adaptation this is because, as the Sunzi bingfa points out, it lacks permanent form. It is its absence of form or disposition (wu xing) that endows it with this continuous readiness and hence its invariable capacity for adaptation. Victory over a sinuous reality in constant metamorphosis can never be won unless by means of a superabundance of mobility, through an even greater power of transformation. All the strategic vocabulary revolves around this principle. Like water, the army must present a perpetual polymorphic plasticity, a formation eternally in movement or transformation which confounds any attempt to detain it or fix it. Like the Way (dao), the first and last principle that governs the functioning of the natural order and that is usually associated with water, ${ }^{30}$ the army cleaves to this principle of absence of form or formation (wu xing) making it impossible for the rival to understand what is happening: imperceptible, impossible to number, indefinable, the troops of the superior army will melt into the subtlety and efficacy of spirits (shen). Like them, it becomes fathomless and beyond the rival's reach. In an analogous manner, in the sphere of persuasion it is not so much a matter of imposing an argument for its own sake but rather swaddling the discourse in nuances and a tone that faithfully adapt to the interlocutor's most intimate preferences. The orator must know how to play with the aspirations and vanity of the person he is addressing, how to exploit his weaknesses to his own advantage and detect the differences between the intentions he declares and the desires he really harbours within. Hence, as with strategies for the battlefield, there are no fixed formulas for convincing or persuading someone of the court. One must adapt and modulate the oral intervention in keeping with the specific characteristics of each listener and each circumstance that arises. As the Guiguzi states quite openly:

The righteous man who disdains riches cannot be seduced by benefits but can be coaxed if one speaks to him of frugality; the valiant warrior who scorns difficulties will be undaunted by fear yet he can be defeated if skilful advantage is taken of his inclination for risk; the wise man can only be approached through calculation and the light of reason and hence one should not try to outwit him through honesty, but rather by making him believe that one is using rational means, and convincing him through adeptness alone. ${ }^{31}$

sphere of the heavens and descending into the very depths of the earth. They can do all this because they have no form." (Zhang Shuangdi 張雙棣 1997: chap. XV, 1578.)

30. See Cheng Guying 陳鼓應 1989: chap. 8, 89.

31. Xu Fuhong 許富宏 2008: chap. X, 152. 
As is also the case in the field of military strategy, persuasive action is organized around a continuous dialectical process that confronts, on the one hand, the will to know, the obligation to penetrate the reality of the other, to shed light on him and lay him bare so as to be able to prevail over him and, on the other, persisting in remaining secret oneself and screened from inquisitive gazes. Gaining ascendancy over one's adversary necessarily involves projecting a light that meets no opposition, that generates total transparency while yet taking on an impenetrable opacity. Indeed, it means bringing one's rival into a relationship of inequality in such a way that he shall remain totally exposed to one's perception, while one remains invisible to his. It is therefore emphasised that one must know all the factors present in the struggle and ensure that each and every manoeuvre is cloaked in the most impenetrable secrecy.

The mouth is the gateway of the heart and the heart is the master of the spirit. Intentions and ideas, inclinations and desires, thoughts and cares, cunning and plans, all pass in and out through this gateway. ${ }^{32}$

The orator, like the military strategist, must be able to expose his opponent to his complete scrutiny and to detect and correctly interpret the most tenuous of clues. He must be so deft that he can bring to the surface the longings, ambitions, thoughts and even plans that are so zealously hoarded inside the individual. The persuader using these psychological skills must then calculate (chuai) gestures, movements and, in particular, words until he has infiltrated the emotional mechanisms of the other (qing). ${ }^{33}$

Even if you possess the way of the former kings, and the planning ability of sages and worthies, without figuring out the inner feelings you will not be able to unmask the hidden and the occult. ${ }^{34}$

What is required, then, is the ability to adapt oneself to the tastes and inclinations of one's interlocutor in order to win his confidence and prompt him to speak so that he will reveal the matter of his concerns and aspirations.

Go along with his tastes and desires in order to perceive his intentions and ideas. ${ }^{35}$

32. Xu Fuhong 2008: chap. I, 15.

33. For a more comprehensive analysis of the term qing 情 within the philosophical and political literature of early China, see the following contributions: Cheng 1999: 31-58; Tang Yijie 2003: 271-281; and Harbsmeier 2004: 69-148.

34. Xu Fuhong 2008: chap. VII, 106-107. On this issue, see Tsao Ding-ren 1985: 135-145; and Wu Xingming 吳興明 1994: 193-201.

35. Xu Fuhong 2008: chap. I, 7. 
It becomes essential to learn the preferences of the person one is addressing so that it will be possible later to adapt one's discourse to these particular conditions. Hence, if Sunzi considered that, in the military domain, it was necessary to defeat the enemy before embarking on the combat against him, on the battlefield of the word it was a question of convincing him or persuading him even before speaking. Just as the success of the military action resides in confronting an already-vanquished adversary, ${ }^{36}$ that of the sophist onslaught resides in addressing a listener who is predisposed to accept one's suggestions in their entirety. The itinerant orators are well aware that the word is never a neutral medium or indifferent with regard to the person pronouncing it, and that the persuasive effect of what is said does not depend on the content of what is uttered alone, nor just on the way or moment in which it is spoken but also, and to a great extent, on the person who is enunciating it. The efficacy of persuasion frequently depends more on credence or trust in the orator than the message he might convey. The same words expressed by two different people never have the same effect on the listener. Once again, the chapter in the Han Feizi devoted to the difficulties of persuasion contains an eloquent illustration of the influence that the favourable or unfavourable inclinations of the sovereign might play in his judging of the words and deeds of his advisers. The anecdote refers to the case of the favourite of the ruler of Wei, Mizi Xia who, in spite of breaking the law by taking the royal carriage for his own private use without seeking permission and having had the temerity to present the ruler with a peach he had previously bitten into, far from being upbraided is extolled because, moved by the affection he has for Mizi Xia, the sovereign judges his conduct from the standpoint of his admiring partiality. Nevertheless, the text also relates that when Mizi Xia's allure and beauty begin to fade with time, the prince, recalling the same behaviour that once won his praises, does not then hesitate to criticise it harshly. The Han Feizi finishes its account with the following reflections:

Hence the words of the man who addresses the ruler when he enjoys his affection are found to be sagacious and right and only reinforce the sovereign's fondness, while the proposals of the man for whom the sovereign has revulsion are always seen to be wrong. I thus recommend that any persuader who offers his advice and words to the ruler should pay the utmost attention to his affections and to what disgusts him before starting to speak. ${ }^{37}$

36. See Yang Bingan 1999: chap. IV, 74-75.

37. Chen Qiyou 2000: chap. XII, 268-269. 
Similarly the Lüshi chunqiu states:

Those who listen to the words of others frequently find them warped and thus hearing these deformations is disturbing. These deformations have many causes although the main one resides in the fact that men are necessarily swayed by their inclinations and aversions. He who looks to the east will not see the wall that is raised in the west, and he who looks to the south will not perceive the north. The same phenomenon occurs with thoughts. ${ }^{38}$

The accomplished orator must win the trust and achieve the emotional attachment of the sovereign so that his words will be judged from the partiality of a propitious subjective dimension or, at least, ensure that they will not be appraised from an antipathy that would be definitive, condemning to the sterility of failure all subsequent efforts at persuasion. However, this is not a matter of gaining trust in the moral sense of the term, which is to say the credence derived from a firm commitment to coherence between the word uttered and the deed to which the word refers, but rather a gullible reliance (or to put it in the terms of military strategy, a seduction or lure) attained through flattery, which in fact serves as a trap or bait, a preliminary ploy to assure the facility of verbal manipulations.

When an orator has ensured that the subjective leanings of his listener will be open to his intentions, he can then deploy a second and definitive smokescreen of ruses and wiles, this time consisting of words. Once the listener's initial psychological barriers or resistance are surmounted, the adroit adviser can completely shatter the relationship between designations (ming) and the effective reality that they are supposed be denoting $(s h i) .{ }^{39}$ Once the link between language and reality is broken, the orator is then in the position to exploit all the possibilities of attraction and charm that are to be found in hollow, self-referential discourse that shuns any obligation to reality. The use of this self-referential language is undoubtedly one of the most characteristic procedures of the orator. His speech is situated on a plane where, without any inconvenient subjugation to the link with reality, words turn back on themselves, generating a sort of circular allenveloping mesh thanks to which they acquire great powers of fascination. This is when the orator is at his most dangerous, when his discourse secretly exudes its maximum efficiency, enveloping and totally beguiling the imagination of the sovereign who, captive to appearances and the majestic connotations conjured up by the empty verbiage, offers no resistance. Imbued with a partiality that favourably and a priori approves of any utterance or opinion without checking

38. Chen Qiyou 2002: chap. XIII.3, 693.

39. See Makeham 1994: 51-84. 
its veracity, the ruler is swept away by the forceful current of alluring discourse while the orator succeeds in inverting the dialectic that should govern relations between sovereign and subject, between dominator and dominated since the exclusive source of absolute authority has been exposed to the gaze and will of the orator who, opaque and impenetrable, hides behind the emptiness of his words and remains out of reach. As in the military domain, where it is essential to shed any constant form ( $w$ u xing) in order to predominate over the adversary, the sphere of persuasion also demands a complete absence of any fixed shape or form so that the orator can impose his will on that of his listener. In no case must the orator harbour any prejudice or opinion but must be permanently available, empty and vacant $(w u)$ so as to be able to mould himself to the contours of his opponent and thereby overcome any resistance the latter may present.

\section{The ghost and the machine: cancelling persuasion through an evanescent ruler}

It is clear, then, that within this context of power relations dominated by the subtleties and scheming that characterise military thinking, any project to counter the orator's attempts to overmaster the sovereign by means of such techniques of persuasion must also proceed from the same logic of strategic ascendancy. Hence a text like the Han Feizi not only relates the fundamental qualities of the persuasive word but also describes the risks entailed by the prevalence of such skills in the bosom of power, while also offering a whole range of advice on how to forestall them. ${ }^{40}$ Of prime interest here are the techniques $(s h u)$ for controlling the bureaucratic apparatus, which were anticipated by such writers as Shen Buhai. ${ }^{41}$ Indeed, the Han Feizi makes a notable effort to establish the procedures that would make it possible, for example, to calibrate the precise correspondence between words and deeds or the divergence between what is said and what is done (shen he xing ming), in such a way that, according to the degree of coincidence between the two spheres, punishments and rewards can subsequently be meted out. ${ }^{42}$ The just application of punishments and rewards, the true foundation of good government and social peace in the Han Feizi, lies precisely in the equivalence between signifier and signified, wherein only one single verifiable reality corresponds to each designation. Nonetheless, since the sovereign is permanently exposed to cunning, falsity and duplicity in utterances

40. On the dangers of the itinerant orators and persuaders, see for example Chen Qiyou 2000: chap. IX, 182 and chap. XLIX, 1114.

41. See Creel 1974.

42. Chen Qiyou 2000: chap. VII, 126. 
that rarely refer to their real object, he needs instruments to enable him to recover the reality lurking behind the words and to achieve a perfect art of listening (ting zhi dao). It is essential to submit the words and behaviour of retainers who address and work for the sovereign to the most painstaking scrutiny, constantly cross-checking the truth of their discourse, the effectiveness with which they perform their duties and the loyalty of their services. Hence, the Han Feizi proffers a full description of the methods the sovereign must be able to employ in order to achieve effective management of the flow of words and information, to substantiate the veracity of the proposals submitted by his subjects: networks of surveillance, secret services for information, scrupulously compared and contrasted probes and inquiries, different forms of interrogation, and so on. ${ }^{43}$

As described above, the parallels between the arts of war and rhetoric are very close. If the success of any persuasive endeavour depends in the last instance on the skills of the orator in adjusting his words to the inclinations, hopes, desires and fears of his listener, then the sovereign's disarming of the persuasive action requires, in turn, the total obliteration of any expression of his emotions so that nobody can intrude on his intimacy. It is hardly surprising, then, that the Zhanguo ce, relates that the advisers of Li Dui, Prime Minister of the state of Zhao, ask him to cover his ears completely (jun jian sai liang er) in order to negate the persuasive influence of the declamations of Su Qin. ${ }^{44}$ It is of course probable that the anecdote offered in the Zhanguo ce is mainly concerned with exalting the extraordinary gifts of oratory attributed to Su Qin. However, the idea that the ruler must diminish and even block his faculties of perception in order to protect himself from the enthralling influence of orators is in no way extravagant. Besieged not only by the suggestive eloquence of wordsmiths, the sovereign is also exposed to their indiscreet gaze which seeks to detect and decipher his deepest emotions as they attempt to arouse his passions, desires and aversions through the power of their words. Hence, at the beginning of the chapter in which the Huainanzi is precisely concerned with describing techniques of control for the exclusive use of the ruler ( $z h u s h u$ ), after which it goes on to state that the ideal sovereign must remain serene, empty and immobile, the following information is offered: "Thus the kings of ancient times wore caps with strings of pearls in front so as to mask their vision and silk plugs in their ears so as to obstruct the acuity of their hearing." ${ }^{45}$ It is not merely a matter of filtering and attenuating the reception in the sovereign's ears

43. Chen Qiyou 2000: chap. XLVIII, 1063-1064 and 1074-1075.

44. Fan Xiangyong 2008: chap. XVII.8, 969.

45. Zhang Shuangdi 1997: chap. IX, 889. See also Wu Zeyu 吳則虞 1962: chap. VII.9, 452-453. 
of the florid, brazen words of the orators, or tempering any agitation or desire he might experience on contemplating beautiful objects, but also of masking the expression on his face when he is confronted with such stimuli so that he is thus shielded from any intrusive scrutiny and able to foil all attempts to discern his preferences and inclinations. This is also why the Han Feizi not only details the procedures of vigilance and inspection that can lay bare those who would address the sovereign, but also insists that the latter must at all times be opaque, impermeable and inaccessible. Bearing in mind that one of the keys to retaining supremacy and thwarting the effects of persuasion consists in ensuring that there is no way that the orator might adapt himself to the sovereign's inclinations, deceit appears as one of the most expedient mechanisms when it becomes necessary to elude and confound intrusive gazes. Secrecy and concealment play a crucial role in aborting any attempt to infiltrate the emotional reality of the ruler. Accepting this basic principle of imperceptibility as the goal to be attained, the Han Feizi readily recommends simulation and dissimulation, or covering up and falsifying his inner condition so as to befuddle the orator's powers of psychological discernment while also, and as a result of this, demolishing his ability to mould himself to his listener.

As for the enlightened ruler, his main concern is complete secretiveness. Therefore when one shows one's delight with someone then the ministers will use generosity to reward that person. When this generosity becomes evident, then the ruler's authority is divided. As for the words of the enlightened ruler, they are therefore blocked off and not to be divulged; they are all secretive and not manifest. ${ }^{46}$

If the ruler shows his hatred, then the various ministers will hide their motives; if the ruler shows his likings, then the various ministers will misrepresent their abilities; if the ruler's desires emerge openly, then the various ministers can avail themselves of this in their attitudes. ${ }^{47}$

[The ruler] does not show his facial expression and the subordinates become plain and straight. ${ }^{48}$

However, in the exposition of all this in the Han Feizi, the ideal ruler must not be content with camouflaging his emotions and preventing them from coming to the surface and being detected by his subordinates but, still more radically, he must also completely suppress all his inclinations, preferences and aversions, which is to say all the elements of his emotional constitution. The text therefore exhorts, "Discard likes, discard dislikes and the ministers will become plain (qu

46. Chen Qiyou 2000: chap. XLVIII, 1072.

47. Chen Qiyou 2000: chap. VII, 130.

48. Chen Qiyou 2000: chap. VIII, 145. 
hao qu wu, chen nai jian su)." ${ }^{49}$ Only thus is it possible to reverse a situation which, at least in principle, would appear to be detrimental to the sovereign's interests, for his words, his actions and his movements are subject to the most tenacious and meticulous scrutiny of the eyes of his numerous underlings, while he can only depend on his own eyes to examine this host of individuals. An anecdote in the form of a dialogue between the King Xuan of Qi (r. 319-301 BCE) and the Master Tang Yi about hunting birds by bow and arrow offers a clear illustration of this situation. The fragment is preceded by words that the Han Feizi puts in the mouth of Shen Buhai when he is urging the sovereign to be extremely cautious with his words and actions since, if he allows any glimpse of his intentions and emotions, his subordinates will adapt to them in order to bemuse and deceive him. The advice that Shen Buhai offers at the end of his speech consists precisely in controlling the advisers and court officials by means of non-action ( $w u$ wei). ${ }^{50}$ Shen Buhai depicts the perfect ruler as a majestic figure, not actively intervening in the government but presiding over it with complete impartiality, in a state of total serenity and imperturbability. ${ }^{51}$ The dialogue between the King Xuan and Tang Yi functions then as a kind of additional explanation of the principle, which has been anticipated by Shen Buhai:

King Xuan of Qi asked Master Tang Yi: "When hunting with stringed arrows, what is the most important issue?"

And Master Tang Yi replied: "The most important issue is being careful about the decoy granary."

And the king asked again: "What do you mean by being careful about the decoy granary?"

[Tang Yi] answered: "The birds observe men with several hundred eyes while man looks at the birds with two eyes: how can one fail to be careful about the decoy granary. That is why I say: the point is in being careful about the decoy granary."

The king said: "Well, then, when one is ruling the world how does one create this decoy granary? Now, the ruler of men looks at the whole state with just two eyes while the whole state looks with myriad eyes at the ruler. How can one turn oneself into a decoy granary?"

49. Chen Qiyou 2000: chap. V, 66.

50. On the political dimension of this notion in ancient China, see Creel 1970: 48-78.

51. A fragment credited to Shen Buhai states: "To speak ten times and ten times be right, to act a hundred times and a hundred times succeed: this is the business of one who serves another as a minister, it is not the way to rule. (十言十當, 百為百當者, 人臣之事, 非君人之道也。)" (See Creel 1974: 350.) 
Tang Yi replied: "Zheng Zhang once said that if one is empty, calm, inactive and invisible, then one is surely able to make this decoy granary." ${ }^{2}$

As I have mentioned, in accordance with Sunzi's principles of the art of war, successful action on the battlefield is accomplished when the strategist is able to ensure that his troops' manoeuvres are imperceptible, invisible to the adversary once they have shed any fixed form, shunned any particular formation and fused with the spirits (shen). This permanent absence of any form or disposition, of any emotion, disturbance and even activity, also defines the absolute domination by means of which the sovereign seeks to undo any attempt at manipulating him through the artfulness of persuasion. ${ }^{53}$ The almost demiurgic condition that the ruler must achieve if he is to avoid being prevailed over by his subordinates with their use of flattering adulation and worthless eloquence expands to the point of his becoming comparable with the Way (dao). In this resolute process of divestment, of emptying and even dehumanisation, the sovereign needs to take on all the negative characteristics of the Way that will attest to his superiority and command: he must appear as impassive, serene, immobile, invisible, unknowable, and so on.

The Way consists in being invisible; its utility lies in being unfathomable. Empty, still, and without occupations, from the darkness he observes others' faults. He sees but is not seen, he hears but is not heard, he knows but is not known. When he hears a proposal he proceeds, and without changing and replacing, by the method of comparison [of words with deed] he observes what happens. [...] He hides his traces, conceals his basic motivations, so those below cannot reach the source [of his intimacy]. ${ }^{54}$

Thus, eliminate likes, eliminate dislikes and, by way of emptying the mind, you will make of the Way your dwelling. ${ }^{55}$

The ruler attains absolute power thanks to his identification with the negative attributes of the Way. In transcending the specific dimension of forms, he unfolds in pure virtuality and prevails over forms because, like the beginning without a beginning that governs the universe, he is able to relinquish them and thereby remain in a state free of any determination. Concealed in the depths of his palace, the sovereign remains in a perfect state of quiescence and inactivity and, without the least sign of emotion, he neutralises the attempts of his underlings to adjust

52. Chen Qiyou 2000: chap. XXXIV, 777.

53. "If the master above is not like a spirit, those below will find something to adapt to him (主上不神, 下將有因)” (Chen Qiyou 2000: chap. VIII, 163).

54. Chen Qiyou 2000: chap. V, 74.

55. Chen Qiyou 2000: chap. VIII, 157. 
their oral interventions to his leanings and predispositions, thus obliging them, as I have noted, to present themselves as simple ( $\mathrm{su}$ ) and straight (zheng). ${ }^{56}$ Now divested of any kind of determination, the sovereign becomes indistinguishable from spirits and phantoms. Like them, unseen he sees, unheard he hears, and unknown he knows. ${ }^{57}$ Just as, when one turns to the invisible spirits, there is no place for calculation or measurements (shen zhi ge si, bu ke du si), ${ }^{58}$ before this subtle, ineffable sovereign, subordinates are unable to scheme in advance and are forced to behave exactly as they are. On becoming dehumanised and identified with the metaphysical principle that regulates the cosmos or with adept and subtle spirits, the ruler turns into a sort of cold, objective entity, an impervious machine that, without being affected by the persuasive dimension of words, examines the correspondence between words and deeds, between denominations and realities. Making the best possible use of the information procured by his networks of surveillance and espionage, the impenetrable opacity in which he is shrouded, and the fact that the ones who must speak (and hence reveal themselves) are his possible adversaries, while he remains silent, the ideal sovereign conceived by the Han Feizi engineers a total disarming of the wily-tongued orators.

To conclude, it is instructive to salvage a brief fragment of the Han Feizi which, after a condensed account of the historical development of humanity and distinguishing three chronological phases (remote antiquity, middle antiquity and the present) as well as their respective modalities of characteristic relations (virtue, cunning, and strength), offers a very different view of the diplomatic

56. To my mind, the use of these two terms in the Han Feizi is not innocent: in the texts associated with the so-called Taoist school, the term $s u$ 素 designates the primordial goodness and simplicity of humanity that had not yet been undermined and contaminated by the political and pedagogical institutions (see, for example, Guo Qingfan 郭慶藩 1968: chap. IX, 334-335); again, the term zheng 正 denotes, in a fair part of the writings associated with Confucianism, the integrity and moral probity of the individual who has been able to complete a process of cultivating himself. Paradoxically, the Han Feizi seeks to procure these qualities among the subjects, not by returning to a primitive society or by completing some form of moral cultivation but, rather, by means of the sovereign's adopting certain sophisticated and immoral techniques.

57. The "Zhong Yong" 中庸 acknowledges the elusiveness of ghost and spirits: "We look for them but cannot see them; we listen for them but cannot hear them (視之而弗見, 聽之而弗聞)" (Shisanjing zhushu十三經注疏 1995: 1628). And, again, the Huainanzi states, "We look for the ghosts and spirits, but they have no form; we listen for them but they have no sound (夫鬼神視之無形, 聽之無聲)” (Zhang Shuangdi 1997: chap. XX, 2050).

58. Mao Shi zhengyi 毛詩正義, in Shisanjing zhushu 十三經注疏 1995: 555. 
mission supposedly led by Zi Gong to the monarch of Qi, i.e. the episode that I mentioned at the beginning of this article:

The state of Qi was preparing to attack the state of Lu and they therefore decided to send $\mathrm{Zi}$ Gong so that he might persuade their adversary. The people of Qi responded [after the meeting], "It is not that you lack rhetoric skills but what we desire are your lands and, naturally, we do not see them in your words." So in the event they sent out their troops, vanquished the army of Lu and extended their realm to within ten miles of the capital of $\mathrm{Lu}^{59}$

I believe that the fact that the Han Feizi does not reproduce the specific content of Zi Gong's speech in the court of Qi is significant. Through this silence, the text somehow seems to be expressing the futility of any persuasive endeavour before a sovereign who, blank, serene and imperturbable, has shed all emotion or prejudice and is not to be swept away by any specious flow of discourse but, rather, responds only to the objective criterion of effective realities. In contrast with the diplomatic success that is attributed to the oratory feat in the Shiji and the Kongzi jiayu, in the version of the Han Feizi Zi Gong's words echo in vain at court. His exhortations, which one imagines to be ingenious and highly accomplished, fail, however, to produce the desired result and, with scant resistance, the venerable lands of $\mathrm{Lu}$ end up being desecrated by the conquering hordes of Qi. Similarly, the absence of the sovereign in the anecdote is highly significant. I believe that if the Han Feizi deliberately omits him precisely at the point where his intervention might be expected, replacing it with the unanimous voice of the people of Qi, it could be because the sovereign has successfully assimilated the techniques that enable him to shed his emotions completely, and has managed to impose strict control over the correspondence between designation and reality within the bureaucratic apparatus. Therefore his presence is no longer necessary. Once he has been able to safeguard the propriety of appellations by thus fixing the univocity of names and things and, by extension, prescribing the just application of punishments and promotions, he is now embracing the ideal of the intangible and impenetrable sovereign who, in the image of the ancestors and natural cycles, silently, effectively and invisibly radiates authority. Under the mandate of this disembodied ruler, the whole population becomes impermeable to the pernicious persuasive action of those who would abuse words and pervert reality through psychological tactics and machinations. Besides exemplifying the eruption of a new virulent historic context, which justifies the resort to violence and coercion by political institutions, the anecdote appears to contain a twofold message about the power

59. Chen Qiyou 2000: chap. XLIX, 1092-1093. 
of speech-making. First, Zi Gong's failure represents the sterility of any rhetoric attempt by an orator in a state where the master of denominations is immune to the effects of verbal subterfuge; and, second, the military invasion of Lu, emblem of Confucian orthodoxy, represents the death throes of Confucius' programme that attempted to subordinate the use of language to a superior moral order. Paradoxically, the version of this story offered in the Han Feizi, in which the mission assigned to $\mathrm{Zi}$ Gong ends in resounding defeat, somehow seems to suggest the attainment of Confucius' longed-for transparent world in which the relationship between designations and realities, between words and facts is perfectly coherent and concordant. Zi Gong's ill-fated diplomatic mission fails precisely because the persuasive capacity of his discourse finds not even a single chink through which to infiltrate and become effective. The rhetorical dimension of his language is therefore conclusively neutralised. In some sense the anecdote offered in the Han Feizi might even be interpreted as something akin to minor revenge in favour of Confucius and against his presumptuous disciple. Nevertheless, the triumph of the chimera that Confucius had once glimpsed comes about in the Han Feizi not by way of the restoration of any moral dimension that would guarantee the honesty and credibility of the words pronounced, but thanks to a strategic device that deactivates any endeavour to bring the sovereign under the sway of words. There is no room for delusion in this regard: the invasion by the army of Qi of the territory of Lu, the Master's birthplace, also symbolises the rout of his project and hence its categorical decline.

\section{BiBLIOGRAPHY}

\section{Primary sources:}

Chunqiu Zuozhuan zhu 春秋左傳注. Edited by Yang Bojun 楊伯君 (1995). Beijing, Zhonghua shuju.

Guiguzi jijiao jizhu 鬼谷子集校集注. Edited by Xu Fuhong 許富宏 (2008). Beijing, Zhonghua shuju.

Han Feizi xin jiaozhu 韓非子新校注. Edited by Chen Qiyou 陳奇猷 (2000). Shanghai, Shanghai guji chubanshe.

Huainanzi jiaoyi 淮南子校譯. Edited by Zhang Shuangdi 張雙棣 (1997). Beijing, Beijing Daxue chubanshe.

Kongzi jiayu shu zheng 孔子家語疏証. Edited by Chen Shike 陳士珂 (1980). Shanghai, Shanghai shudian.

Laozi jinzhu pingjie 老子今註平介. Edited by Cheng Guying 陳鼓應 (1989). Beijing, Zhonghua shuju.

Lunheng jiaoshi 論衡校釋. Edited by Huang Hui 黃暉 (1990). Beijing, Zhonghua shuju. 
Lunyu jishi 論語集釋. Edited by Cheng Shude 程樹德 (1980). Beijing, Zhonghua shuju.

Lüshi chunqiu xin jiaoshi 呂氏春秋新校釋. Edited by Chen Qiyou 陳奇猷 (2002). Shanghai, Shanghai guji chubanshe.

Mao Shi zheng yi 毛詩正義. In Shisanjing zhushu 十三經注疏 edition (1995). Yangzhou, Jiangsu Guangling guji.

Mengzi jin zhu jin yi 孟子今註今譯. Edited by Wang Yunwu 王雲五 (1984). Taibei, Taiwan Shangwu.

Shang jun shu zhuizhi 商君書錐指. Edited by Jiang Lihong 蔣禮鴻 (1986). Beijing, Zhonghua shuju.

Shiji 史記 (1959). Primarily composed by Sima Qian 司馬遷 ( ca 145-ca 86 BCE). Beijing, Zhonghua shuju.

Shiyi jia zhu Sunzi jiaoli 十一家注孫子校理. Edited by Yang Bingan 楊丙安 (1999). Beijing, Zhonghua shuju.

Shuo yuan jiaozheng 說苑校証. Edited by Xiang Zonglu 向宗魯 (1989). Beijing, Zhonghua shuju.

Xunzi jijie 菂子集解 (1997). Edited by Wang Xianqian 王先謙 (1842-1918). Beijing, Zhonghua shuju.

Yanzi chunqiu jishi 晏子春秋集釋. Edited by Wu Zeyu 吳則虞 (1962). Beijing, Zhonghua shuju.

Yuejue shu jiaoshi 越絕書校釋. Edited by Li Bujia 李步嘉 (1992). Wuhan, Wuhan Daxue chubanshe.

Zhanguo ce jian zheng 戰國策戔證. Edited by Fan Xiangyong 范祥雍 (2008). Shanghai, Shanghai guji chubanshe.

Zhong Yong 中庸. In Shisan jing zhu shu 十三經注疏 edition (1995). Yangzhou, Jiangsu Guangling guji.

Zhuangzi jishi 莊子集釋. Edited by Guo Qingfan 郭慶藩 (1968). Beijing, Zhonghua shuju.

\section{Secondary sources:}

BILleter, Jean-François (2005). Études sur Tchouang-tseu. Paris, Allia.

Cheng, Anne (1999). "Émotions et sagesse dans la Chine ancienne. L'élaboration de la notion de qing dans les textes philosophiques des Royaumes Combattants jusqu'aux Han." Études chinoises, no. 18.1-2: 31-58.

Creel, Herrlee G. (1970). "On the origin of wu-wei." In What is Taoism? And Other Studies in Chinese Cultural History. Chicago, The University of Chicago Press.

Creel, Herrlee G. (1974). Shen Pu-Hai, A Chinese Political Philosopher of the Fourth Century BC. Chicago, The University of Chicago Press.

Garrett, Mary (1993). "Pathos Reconsidered from the Perspective of Classical Chinese Rhetorical Theories." Quarterly Journal of Speech, no. 79: 19-39.

HARBSMEIER, Christopher (2004). "The Semantics of Qing in Pre-Buddhist Chinese." In Eifring, H. (ed.), Love and Emotions in Traditional Chinese Literature. Leiden, Brill.

Hsu, Cho-yun (1965). Ancient China in Transition. An Analysis on Social Mobility (770-222 BC). Stanford, Stanford University Press. 


\section{Albert Galvany}

Knoblock, John (1988). Xunzi: A Translation and Study of the Complete Works. Stanford, Stanford University Press.

LeVI, Jean (1989). Les Fonctionnaires divins: politique, despotisme et mystique en Chine ancienne. Paris, Éditions du Seuil.

LEVI, Jean (1992). "L'art de la persuasion à l'époque des Royaumes Combattants." Extrême-Orient, Extrême-Occident, no. 14: 49-89.

LEVI, Jean (2002). Confucius. Paris, Éditions Pygmalion.

LEVI, Jean (2007). "Les 'circulateurs de savoirs' au temps des Royaumes Combattants." In Jacob, Christian (ed.), Lieux de savoir. Espaces et communautés. Paris, Albin Michel: 805-823.

LiN, Yü-sheng (1974-1975). "The evolution of the pre-Confucian meaning of Jen and the Confucian concept of moral autonomy." Monumenta Serica, no. 31: 172-204.

Lloyd, G. E. R. (1996). Adversaries and Authorities. Investigations into Ancient Greek and Chinese Science. Cambridge, Cambridge University Press.

Makeham, John (1994). Name and Actuality in Early Chinese Thought. Albany, NY, State University of New York Press.

Milburn, Olivia (2010). The Glory of Yue. An Annotated Translation of the Yuejue shu. Leiden, Brill.

Nivison, David S. (1999). "The Classical Philosophical Writings.” In Loewe, Michael \& Shaugnessy, Edward L. (eds), The Cambridge History of Ancient China. Cambridge, Cambridge University Press: 745-812.

RaphaLs, Lisa (1992). Knowing Words: Wisdom and Cunning in the Classical Traditions of China and Greece. Ithaca, NY, Cornell University Press.

TANG, Yijie (2003). "Emotion in Pre-Qin". Philosophy East and West, no. 53.2: 271281.

Tsao, Ding-ren (1985). The Persuasion of Kuei Ku Tzu ( $\mathrm{PhD}$ dissertation). The University of Minnesota.

Wu, Xingming 吳興明 (1994). Mouzhi, shengzhi, zhizhi: Moulue yu Zhongguo guannian wenhua xingtai 謀智, 聖智, 知智: 謀略與中國觀念文化型態. Shanghai, Shanghai sanlian shudian.

ZHUAN, Jianping 傳劍平 (1995). Zonghengjia yu Zhongguo wenhua 縱橫家與中國文 化. Taibei, Wen Yin chubanshe. 
The Dynamics of Psychological Persuasion in Ancient China

\section{Glossary}

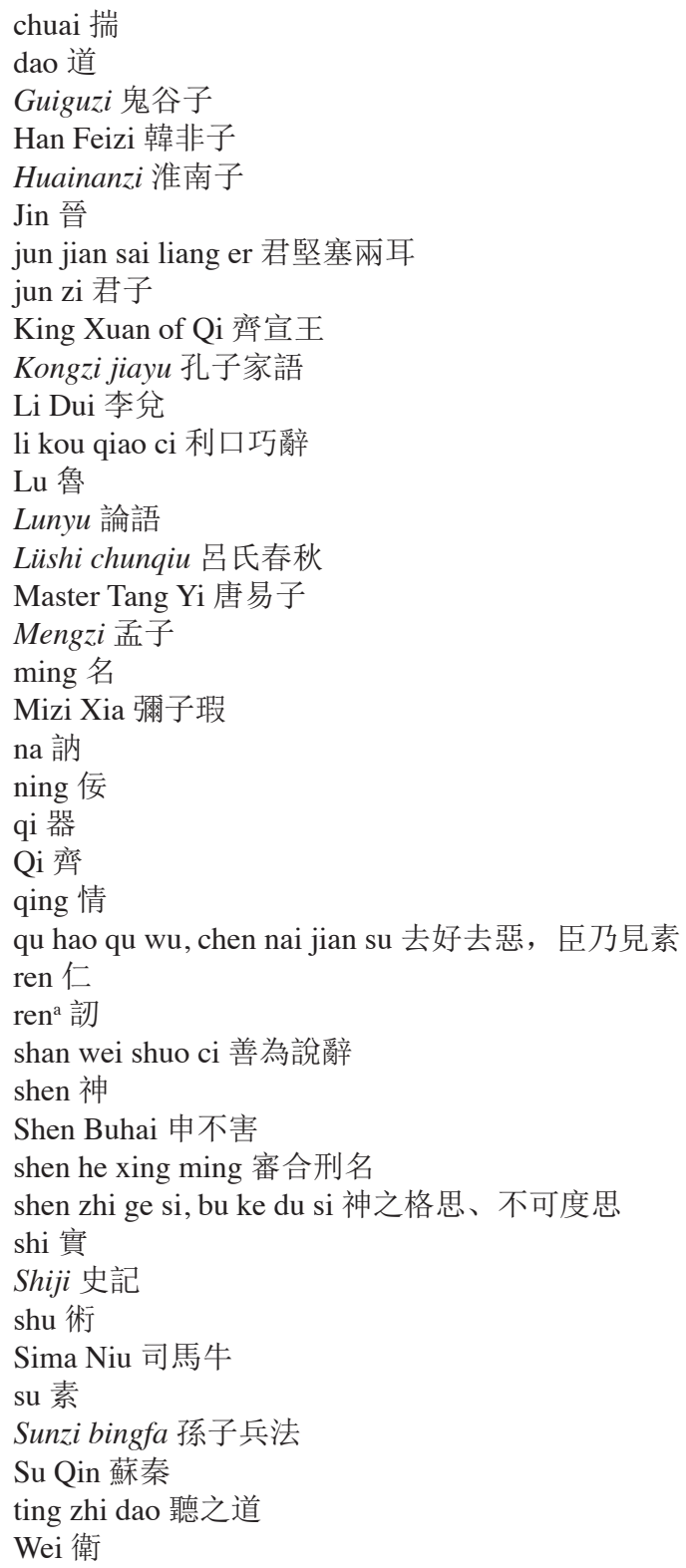




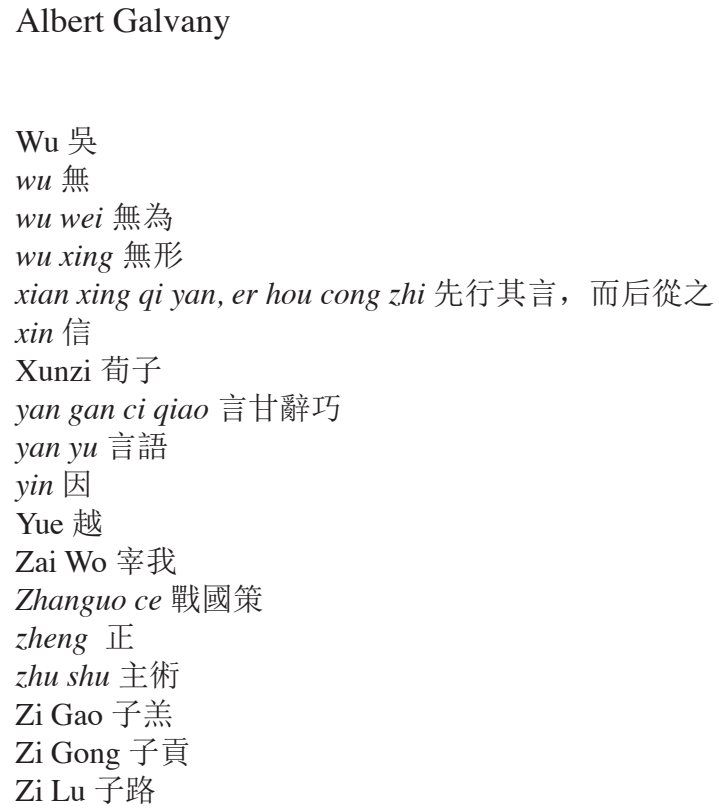

$\mathrm{Wu}$ 吳

$w u$ 無

wu wei 無為

wu xing 無形

xian xing qi yan, er hou cong zhi 先行其言, 而后從之 $\operatorname{xin}$ 信

Xunzi 荀子

yan gan ci qiao 言甘辭巧

yan yu 言語

yin 因

Yue 越

Zai Wo 宰我

Zhanguo ce 戰國策

zheng 正

zhu shu 主術

$\mathrm{Zi} \mathrm{Gao}$ 子羔

Zi Gong 子貢

$\mathrm{Zi} \mathrm{Lu}$ 子路 